\title{
Emotional intelligence through the Bhagavad-Gita
}

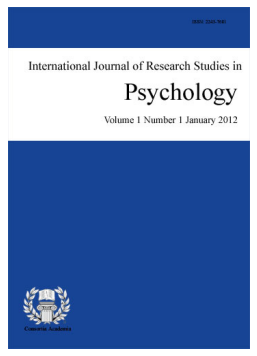

Gayathri, N.

VIT University, Tamilnadu, India (ngayathri@vit.ac.in)

Meenakshi, K.

VIT University, Tamilnadu, India (k.meenakshi@vit.ac.in)

\begin{abstract}
"Yam hi na vyathayanthyethe purusham purusharshabha Samadhukha sukham dheeram somruthathvaya kalpathe” [In Sanskrit]
\end{abstract}

This analytic sloka from the Bhagavad-Gita (Chapter II, Verse 15) sums up the entire concept of Emotional Intelligence (EI). It says: a person who is calm and remains unperturbed by either pain or pleasure is the one who attains immortality. The theory of EI which has been popularized by Goleman can be traced down to David Wechsler, who, as early as in 1940 said that intelligence does not denote just the cognitive abilities of a person but the non-cognitive abilities as well. This idea was again put forward by Howard Gardner in 1983 when he brought forth the multiple intelligence theory and said that intrapersonal and interpersonal skills are as important as the traditional concept of intelligence which focused on the cognitive skills alone. In 1990, Mayer and Salovey introduced the concept of Emotional Intelligence as a distinct form of intelligence which can be measured and evaluated. This paper analyses the possibility of developing the theory of EI into a more comprehensive one. It compares and contrasts the theory of EI against the concept of emotions as discussed in the Bhagavad-Gita and explores the possibilities of finding specific methods through which a person's emotional competencies can be enhanced by incorporating the ideals of Sri Krishna as discussed in the Bhagavad-Gita.

Keywords: emotions; human mind; emotional intelligence; Bhagavad-Gita 


\section{Emotional intelligence through the Bhagavad-Gita}

\section{Introduction}

The human mind is the most fascinating thing which has intrigued and mesmerized philosophers and scientists alike. The power of human mind cannot be fathomed. It is this 'mind' which makes a human being unique and different from other creations. The Indian philosophy deals extensively on the power of human mind. In fact, it can be said that the oriental philosophy is primarily concerned about a person's well being by controlling his mind. It emphasizes that it is the mind that defines a person. In the 'Ramayana' (one of the Indian epics), when Hanuman (Lord Rama's messenger in search of his wife Sita) searches for Sita in Ravana's (the demon king who abducted Rama's wife, Sita) palace, he scourges the entire city not leaving even an inch uninspected. This search takes him to the inner chambers of Ravana and is compelled to look for Sita among the various cohorts of Ravana. As Hanuman searches Lanka (Ravana's city) in the night, he is forced to look at women sleeping in various postures and some even scantily dressed. He asks himself whether he was doing the right thing because he was a sworn Brahmachari (a celibate), but quickly upbraids himself on his misgivings as he clarifies to himself that it is the mentality which decides whether a man is of good character or not. He had not been tempted or affected in the least looking at those women. This detachment ensures that he remains pure and chaste without any blemish on his vow of Brahmacharya. It is the thought that counts and not the action.

"mano matram jagat, mano kalpitam jagat" [In Sanskrit] - "the world is as the mind sees and feels it; the world is as the mind thinks of it' (as quoted by T. N. Sethumadhavan, 2010).

A man's destiny is shaped by his thoughts and not by mere actions. A man is still considered pure even when he does certain unacceptable actions only per force, (on the demands of the situation or having a larger interest in mind) but with his mind detached. Like the one described above, there are innumerable instances in the Indian epics and the puranas which uphold this view and the eastern philosophy sees this doctrine of controlling one's mind as a way of living and not as some abstract philosophical thought. It believes and imbibes the responsibility that every man is accountable for each and every act and thought of his. This accountability brings caution and enables him to restrain himself from thinking or acting in haste. The mind has the potential of shaping a man's destiny. The five senses of a man are capable of enmeshing him in the mire of emotional upheavals. The mind which is superior to the senses, if controlled and focused, helps a man attain peace from within. The recent theory of 'Emotional Intelligence' which has gained popularity also wakes up to the importance of understanding and controlling one's emotions as the defining factor of one's success or failure in life. The advocates of emotional intelligence (EI) claim that it is a person's capacity to understand his own emotions and those of others and the use of this knowledge to the best of his interests that helps him climb the ladder of success.

While the Indian philosophy as well as EI calls attention to the power of emotions, they both differ in certain basic aspects. The EI focuses on a man's success from the materialistic point of view - an emotionally intelligent person becomes a successful manager, becomes adept in handling relationships etc. - whereas, the Indian texts have a more holistic approach. They see the mind as an instrument which has the potential to lead a man to eternal happiness or to perpetual suffering. It isn't something that begins and ends with this life on earth, but that which paves way for many more such births and thus, if a man does not control his senses, he falls into the abyss of birth and rebirth, trapped in this mortal world for an eternity. The Indian philosophy thus takes both life and death into thought. For the Indian philosophers, life and death complement each other and the one loses its meaning without the other. For them life on this earth is a preparation for the life after death. They believe in the theory of 'Karma' - every thought and action of a person has its repercussions. A man's 'Karma' binds him to this world of suffering and an enlightened man strives to escape this web of 'Karma' by controlling his thoughts and actions and focusing them on the Supreme Being. This approach gives a different dimension to the understanding of the importance and control of mind for the Indian philosophers and thus distinguishes them 
from the advocates of the theory of emotional intelligence. An analysis and comparison of the Indian philosophical approach to that of EI is sure to pave way for a better understanding on the power of emotions and the way to control them.

There are innumerable texts, in fact a gamut of literature - the Upanishads, the epics, the Vedas - which discuss in detail the nature of human mind and the significance of controlling it. As it is impossible to bring in all these texts, the Bhagavad-Gita (also referred to as the 'Gita') which is considered the fifth Veda, the essence of all the Upanishads, is taken for the study. The 'Gita' is considered to be the milk of all Upanishads and Krishna is the cowherd who milked it for Arjuna.

Sarvopanishadho gavo dhogdha gopalanandanah

Partho vatsah sudhirbhoktha dhugdham githamrutham mahath [In Sanskrit]

(Bhagavad-Gita - Dhyanasloka 4)

As far as 'Emotional Intelligence' is concerned, the three major models proposed by Mayer and Salovey, Reuven Bar-On and Goleman, are taken for the study.

\section{The theory of Emotional Intelligence}

Though the field of emotional intelligence is a fairly new one - the word 'emotional intelligence' itself was coined first and used in literary writing by Peter Salovey and John Mayer in 1990 (Cherniss, 2000). The concept has caught on like wild fire as it explains and provides evidence on how people with a good IQ sometimes fail and those who were school dropouts and considered stupid go on to become the most successful ones in their fields (Goleman, 1996). Thus, the world has woken up to the fact that intellectual and cognitive abilities alone do not help a person, but it is his emotional intelligence - an ability to understand and control his emotions and that of others for the best possible results - that makes him a complete man and takes him on the path of success.

John Mayer, Peter Salovey, David Caruso, David Goleman, Reuven Bar-On - some of the forerunners in the research on emotional intelligence list out various characteristics which decide a person's emotional intelligence. While Mayer and Salovey (1990) take EI as a purely cognitive ability, - EI can be intellectually understood, measured and developed in a person - Goleman and Reuven Bar-On view it as a personality trait. While Mayer and Salovey's four branch model of EI lays emphasis on emotional perception, emotional assimilation, understanding and management (Mayer, Salovey, \& Caruso, 2004), Reuven Bar-On (2002) agrees on the qualities of emotional self awareness, self-actualization, interpersonal relationship, reality testing, stress tolerance, optimism, happiness, etc. as those that decide the emotional intelligence of a person. Goleman (1998) on the other hand points out to emotional self awareness, self control, empathy, problem solving, conflict management, leadership, etc. as the characteristics of an emotionally intelligent person. All these models have been identified by their respective advocates for certain specific purposes. The mixed ability model proposed by Reuven Bar-On emphasizes on how the personality traits influence a person's general well being and Goleman's model focuses on workplace success (Stys \& Brown, 2004).

Mayer and Salovey's four branch model understands emotional intelligence as a cognitive ability and presents the four levels through which a person becomes emotionally intelligent. The first step is emotional perception - an ability to be self-aware of emotions and to express them accurately. When a person is aware of the emotions he is experiencing, he moves on to the next level - emotional assimilation - to distinguish between the different emotions he is undergoing and also identify those emotions that affect his thought process. This understanding leads him to - emotional understanding - an ability to understand complex emotions and also to recognize the transition from one emotion to another. By then he becomes adept in dealing with his emotions and thus is able to manage his emotions - to connect or disconnect from any emotion at any given situation. This gives him complete control over his impulses and thus is able to think, analyze and behave rationally in any 
situation. The entire process is purely an intellectual procedure. Emotions are understood and controlled through intellectual prowess.

In contrast, Reuven Bar-On and Goleman propose the mixed ability models which include certain personality traits as well. Bar-On's (2002) model of emotional intelligence relates to the potential for performance and success, rather than performance or success itself, and is considered process-oriented rather than outcome-oriented. It strives to identify in a person the latent capability of being emotionally intelligent. His model outlines five components - intrapersonal, interpersonal, adaptability, stress management, and general mood components (Bar-On, 2002). They are similar to Mayer and salovey's model on emotional self awareness, self control, self expression, and empathy, but along with these aspects, Bar-On includes reality testing, - the ability to assess the relation between the emotionally experienced and the actual nature of an object - stress tolerance, and the strength to stay happy and optimistic in the face of adversity. Goleman's model deviates slightly as he includes organizational awareness, leadership and teamwork and collaboration along with self awareness, self control and empathy, as his focus is on workplace success. Thus, all these three models agree on the importance of understanding the emotions in one's own self and others, then managing and controlling them.

One major drawback is that these models strive to identify whether a person is emotionally intelligent or not, but does not give any specific guidelines as to how the person can actually enhance his emotional intelligence. By making the person realize his shortcomings, they believe, he will be able to work towards resolving them as well. They do harp on the importance of consciously identifying their emotions and with that knowledge have a better control over their emotional impulses, but the question remains whether it is actually effective. The models rely to a great extent on self report where the subject assesses himself on his emotional well being. How far can they be reliable is a question that cannot be answered convincingly (Petrides, 2011). It is an irrefutable truth that the researchers after the initial study of emotions and their disruptive nature have branched out into identifying the emotionally competent people through the various models. The theory as such has not been revised or improved upon. More research should be diverted into ascertaining the nature of emotions and the human mind that is fountain head of these emotions. The means of controlling the mind and a foolproof way to check impulsive emotions should be given more prominence. To put it in a nutshell we can say that the theory of emotional intelligence is still in its evolving stage from whence it has to go a long way in identifying the causes of emotional instability in people and giving reliable solutions for the problem.

\section{Emotional Intelligence as in Bhagavad-Gita}

The Bhagavad-Gita on the other hand, stands tall as an authority in not only identifying the nature of emotions but also in showing a way to come out of the darkness of emotional instability. It is in the form of a dialogue between the emotionally disturbed (Arjuna) and the universal master (Krishna) and remains an irrefutable answer to many a modern day man's dilemma or confusion. The background is the Kurukshetra war where the first cousins stand against each other when Arjuna, the warrior non-pareil loses his nerve and refuses to fight. His mind is a cauldron of emotions gripped with the moral dilemma of to do or not to do. At the same time, an insight into Arjuna's character reveals to us that he is not a person who is easily perturbed. He has in the past exhibited exemplary restraint and discipline even at the most challenging times. When Draupadi becomes the wife of all the five brothers in spite of being won by him in the swayamvar, he does not falter or give in to any kind of emotion. He perfectly understands his mother Kunti's decision as the motive behind it was politically strengthening themselves against the Kauravas - Panchala was a powerful kingdom - and also the fact that Kunti did not want any dissention among the brothers because of Draupadi.

Even now when his mind is in conflict whether he should fight the war or not, he is able to intellectually analyze and understand his situation. He is in an emotional upheaval but, that does not deter him from assessing himself accurately. Arjuna, is able to define his problem in clear terms, but, supplicates to Krishna for help. He says - 
karpanyadosopahatasvabhavah prcchami tvam dharmasammudhacetah

Yacchreyah syanniscitam bruhi tanme sisyate'ham sadhi mam tvam prapannam [In Sanskrit]

With my nature overpowered by weak commiseration, with a mind in confusion about duty, I supplicate Thee. Say decidedly what is good for me. I am Thy disciple. Instruct me who have taken refuge in Thee." (as translated by Swami Swarupananda, 1996).

(Bhagavad-Gita, Ch. II, Sloka 7)

Arjuna knows that he is torn between his loyalty to his brothers, his love and respect for his grandsire (Bhishma) and Guru (Drona), and his responsibility towards his kinsmen. Thus, it is not that Arjuna is unaware of his condition. This streak of his character questions the theory of EI which believes that when a person is able to analyze and understand his emotional state, he has better control over himself and will be able to take the right decision. He is emotionally intelligent in the sense that he is able to identify the emotions overpowering him Karpanyadosopahatasvabhavah (with my nature overpowered by weak commiseration). Then, what stops him from choosing the right course of action? Does mere knowledge or intelligence of a person's emotional situation give him the power of control? Later also, while discussing the nature of emotions, Arjuna asks Krishna about the person who is emotionally stable - the 'sthithapragnya'. It has to be well noted that it is Arjuna who first speaks about a sthithapragnya, and not Krishna.

Sthitaprajnasya ka bhasa samadhisthaya kesava

Sthitadhih kim prabhaseta kimasita vrajeta kim [In Sanskrit]

What, O Kesava, is the description of a man of steady wisdom, merged in Samadhi? How (on the other hand) does the man of steady wisdom speak, how sit, how walk? (Swami Swarupananda, 1996).

(Bhagavad-Gita, Ch. II, Sloka 54)

This throws light on Arjuna's knowledge about people who are of steady emotions, unperturbed by the dualisms of pleasure or pain, good or evil, loss or gain. Thus, we see that Arjuna is not only perfectly aware of his own emotional state, but is also aware of that state of mind which promises peace and wisdom. According to the theorists of EI, this awareness should have empowered him against the instabilities of human mind which is wrought by confusion in trying situations. Then why does Arjuna take refuge in Krishna to enlighten and guide him towards the right direction. Why doesn't his emotional intelligence give him emotional stability? Even the best among men stand helpless against the onslaught of the senses - indriyani pramathini haranti prasabham manah - the turbulent senses snatch away the mind of even a wise man. So what is the remedy? How can a person become emotionally stable (Sthithapragnya)? While treating a problem it becomes essential that the cause is ascertained first. Krishna does the same. What are the reasons for any man's emotional upheaval or turmoil? Attachment and lust or desire, he says, is the underlying cause of all disruptive emotions.

Dhyayato visayanpumsah sangatesupajayate

Sangatsanjayate kamah kamatkrodho'bhijayate [In Sanskrit]

Thinking of objects, attachment to them is formed in a man. From attachment longing, and from longing anger grows.

krodhadbhavati sammohah sammohatsmrtivibhtamah

smrtibhramsadbuddhinaso buddhinasatpranasyati [In Sanskrit]

From anger comes delusion, and from delusion loss of memory. From loss of memory comes the ruin of discrimination, and from the ruin of discrimination, he perishes. (Swami Swarupananda, 1996).

(Bhagavad-Gita, Ch. II, Sloka 62, 63) 
In just two slokas Krishna captures the tendency of the human mind to be led astray by desire and attachment. Attachment is the root of all misery, says the 'Gita'. Attachment leads to desire; desire when not fulfilled leads to anger; anger to delusion; delusion to indiscriminate action which in turn leads a man to his ruin. Attachment is the web that ensnares a person in this materialistic world. This world is nothing but an illusion or 'Maya' which blinds a person and prevents him from realizing the Supreme Being. A person who has realized this eternal truth severs his attachment with this 'unreal' world - 'unreal' because, nothing in this world is permanent. It is constantly changing. If this world is unreal, then what is 'real'? The 'Atman' or the soul which is the embodiment of the Supreme Being is the 'real', the unchanging and the permanent. A sthithapragnya has the knowledge that distinguishes between the 'real' (the permanent; the Atman or the soul) and the 'unreal' (the impermanent). He has firmly anchored himself in the realization of this immovable, unchangeable, indestructible 'self' or the 'Atman'. This enables him to detach himself from this 'unreal' world and steer his thoughts towards the 'real', the Atman. But, when this concept of 'real' and the 'unreal', remains elusive to even great intellectuals, where does the common man stand? How does he protect himself from attachment, lust and desire that shrouds his mind and prevents him from clear thinking and right decision at the right time? The greatness of the Bhagavad-Gita lies in the fact that it addresses the problem from the point of view of a layman, an intellectual as well as the one who seeks enlightenment. The doctor who diagnoses the problem prescribes the medicine as well. For the common man, Krishna advises the path of 'karma yoga' - the path of detached action.

\section{karmanyevadhikaraste ma phalesu kadachana}

ma karmaphalaheturbhuma te sango'stvakarmani [In Sanskrit]

Thy right is to work only; but never to the fruits thereof. Be thou not the producer of the fruits of (thy) actions; neither let thy attachment be towards inaction.

(Bhagavad-Gita, Ch. II, Sloka 47)

yuktah karmaphalam tyaktva santimapnoti naisthikam

ayuktah kamakarena phale sakto nibadhyate [In Sanskrit]

The well-poised, forsaking the fruit of action, attains peace, born of steadfastness; the unbalanced one, led by desire, is bound by being attached to the fruit (of action). (Swami Swarupananda, 1996).

(Bhagavad-Gita, Ch. V, Sloka 12)

The way to emotional stability is to remain unattached to the fruits of action. It must be noted that Krishna does not denounce action or asks one to renounce everything in life. He keeps reiterating that action is always better than inaction - karma jyayo hyakarmanah. One must follow and fulfill his 'swadharma', his obligatory duties. When he does that without expecting anything in return, he becomes a 'karma yogi' which is the first step towards becoming a 'sthithapragnya' - the emotionally stable person. It is the duty of a person says 'Gita', to act according to his dharma. Upholding this dharma of his without getting attached to the fruits of his action is the best way to tackle any conflicting situation. One should not claim the fruits of his actions because the moment he does that, he is bound. This bondage will cloud his sense of right and wrong and thus lead him to misery. Thus, negating or ignoring the fruits of one's actions, one should focus on one's duty alone. When a person firmly anchors himself to this principle he is not swayed by any confusion or dilemma. His mind is clear; his judgment is not muddled; he takes the right decisions; he succeeds in life.

But how does one choose between conflicting obligations like the one Arjuna faces - whether to forego his duty as a Kshatriya, to fight or go ahead and kill his own kith and kin for attaining the kingdom. What should be the guiding factor in such situations? Actions which result in societal well being - Lokasangrahamevapi sampasyankartumarhasi - is the answer. That which denounces selfishness and results in the well being of the society at large is the best choice. Krishna advises Arjuna to fight the war not on the selfish grounds of attaining the kingdom but as an obligatory duty. It was not Arjuna who sought the war. Having challenged, he cannot, should not step back and refuse to fight. Further it is also his duty as a Kshatriya to fight adharma, the evil forces 
and protect mankind. It is for these selfless reasons that Arjuna must fight whatever be the result. He may win or lose, but, fight he must. This selflessness and detachment will free him from bondage and render him guiltless of killing his kith and kin. When this detachment to the fruits of his action is practiced by a person, his mind becomes free from worries and confusion. When the mind is free and uncluttered, it is able to think clearly and clarity of thought is the hallmark of any successful person. Thus, Krishna advises Arjuna,

Sukhaduhkhe same krtva labhalabhau jayajayau

tato yuddhaya yujyasva naivam papamavapsyasi [In Sanskrit]

Having made pain and pleasure, gain and loss, conquest and defeat, the same, engage thou then in battle. So shalt thou incur no sin. (Swami Swarupananda, 1996)

(Bhagavad-Gita, Ch. II, Sloka 38)

Thus, we see that Krishna not only diagnoses the root cause of all emotional disturbances, but also gives solution to control them and guides one in taking the right decisions while facing difficult, challenging situations.

\section{Conclusion}

"If we, as a body of science and practice, suppress critical comments, surround ourselves with insiders, and fail to ask the tough questions, we may have a happier field, but a less effective one" (Caruso, 2003). For any field to flourish, positive criticism and an influx of fresh, newer ideas are indispensable. When the above insights from the eastern philosophy are incorporated into the theory of emotional intelligence, it becomes more complete in thought. The lessons of Krishna to Arjuna on the battlefield transcend religions, cultures, and beliefs and are not bound by time or age. This time tested, immortal song of the divine has been a beacon light of hope and guidance to many a lost soul and will continue to be so. When both the theory of EI and the Bhagavad-Gita complement each other, they are sure to show the way for the modern man lost in the mire of confusion, conflict and moral dilemmas.

\section{References:}

Bar-On, R. (2002). Bar-on emotional Quotient Inventory (EQ-I): Technical manual. Toronto, Canada: Multi-Health Systems.

Cherniss, C. (2010). Emotional intelligence: What it is and why it matters. Annual meeting of the society for industrial and organizational psychology, New Orleans, LA.

David, C. R. (2003). Defining the inkblot called emotional intelligence: Issues in emotional intelligence. Retrieved October 16, 2011, from http://www.eiconsortium.org

Education System in Ancient India. (2010). Retrieved November 1, 2010, from http://www.sciforums.com/Education-System-In-Ancient-India-t-16676.html

Goleman, D. (1998). Emotional intelligence. New York: Bantam.

Goyandka, J. (1994). The secret of Karmayoga. Govind bhavan karyalaya. Gita Press. Gorakhpur.

Mayer, D. J., Salovey, P., \& Caruso, D. R. (2004). Emotional intelligence: Theory, findings and implications. Psychological Inquiry, 15(3), 197-215. <http://dx.doi.org/10.1207/s15327965pli1503_02>

Petrides, K. V. (2011). Ability and trait emotional intelligence. The Wiley-Blackwell handbook of individual differences. Blackwell Publishing Ltd.

Ray, P. (2011). Yagnaseni: The story of Draupadi. Trans. Pradip Bhattacharya. Rupa Publications Pvt. Ltd. Salovey, P. \& Mayer, J. D. (1990). Emotional intelligence. Baywood Publishing Co., Inc.

Sethumadhavan, T. N. (2012). From mind to no mind - Samadhi (Nirvana): A difficult but not impossible journey. Retrieved December 8, 2012, from http://www.esamskriti.com/essay-chapters/From-Mind-to-No-Mind- -Samadhi-(Nirvana)-1.aspx 
Gayathri, N. \& Meenakshi, K.

Stys, Y., \& Brown, S. L. (2011). A review of the emotional intelligence literature and implications for corrections. Research Branch. Correctional Service of Canada.

Swarupananda, S. (1996). Srimad Bhagavad Gita. Advaita Ashrama, Calcutta, 16th Impression. 